\title{
Light/heat effects on RNA editing in chloroplast NADH-plastoquinone oxidoreductase subunit 2 (ndhB) gene of Calotropis (Calotropis procera)
}

\author{
Ahmed M. Ramadan ${ }^{1,2}$ (D)
}

\begin{abstract}
Background: RNA editing is common in terrestrial plants, especially in mitochondria and chloroplast. In the photosynthesis process, NAD dehydrogenase plays a very important role. Subunit 2 of NADH-dehydrogenase is one of the major subunits in NAD dehydrogenase complex. Using desert plant Calotropis (Calotropis procera), this study focuses on the RNA editing activity of ndhB based on light time.

Results: NdhB (NADH-dehydrogenase subunit 2) gene accession no. MK144329 was isolated from Calotropis procera genomic data (PRJNA292713). Additionally, using RNA-seq data, the cDNA of the $n d h B$ gene of $C$. procera was isolated at three daylight periods, i.e., dawn (accession no. MK165161), at midday (accession no. MK165160), and pre-dusk (accession no. MK165159). Seven RNA editing sites have been found in several different positions (nucleotide no. C467, C586, C611, C737, C746, C830, and C1481) within the ndhB coding region. The rate of these alterations was deferentially edited across the three daylight periods. RNA editing rate of $n d h B$ gene was highest at dawn, $(87.5,79.6$, $78.5,76,68.6,39.3$, and $96.9 \%$, respectively), less in midday $(74.8,54.1,62.6,47.4,45.5,47.4$, and $93.4 \%$, respectively), and less at pre-dusk $(67,52.6,56.9,40.1,40.7,33.2$, and 90\%, respectively), also all these sites were validated by qRT-PCR.

Conclusion: The differential editing of chloroplast $n d h B$ gene across light periods may be led to a somehow relations between the RNA editing and control of photosynthesis.
\end{abstract}

Keywords: Light, RNA editing, ndhB, Desert plant, Calotropis (Calotropis procera)

\section{Background}

RNA editing is one form of post-transcriptional changes, which include nucleotide insertion, deletion, or modification [1, 2]. This mechanism was first discovered in mitochondrial trypanosomes [3]. The typical form of animal RNA editing is the alteration of adenosine (A) to inosine (I) which is interpreted as guanosine, this is achieved through the activity of adenosine deaminases [1]. Also, the conversion of cytidine to uridine was

\footnotetext{
Correspondence: ahmedramadan782@yahoo.com; aamara@kau.edu.sa 'Department of Biological Sciences, Faculty of Science, King Abdulaziz University (KAU), PO Box 80141, Jeddah 21589, Saudi Arabia

${ }^{2}$ Department of Plant Molecular Biology, Agricultural Genetic Engineering Research Institute (AGERI), Agriculture Research Center (ARC), Giza, Egypt
}

reported in the apolipoprotein $\mathrm{B}$ gene and produced by (apobec/ACF) editosome [4]. Terrestrial plants RNA editing is common in mitochondrial and chloroplast genes. Cytidine to uridine nucleotide conversion is observed in most transcripts plant organelle [5, 6]. Fortythree editing sites in the chloroplast genome [7] and 619 sites mitochondrial genome [8] were investigated in Arabidopsis (Arabidopsis thaliana). RNA editing is found in coding sequences, long non-coding RNAs, introns, tRNAs, microRNAs, and rRNAs [9, 10]. Most RNA editing cases in coding regions where integrated biological functions occur in the first or second codon position [11]. The efficiency of chloroplast transcript editing varies among developmental stages, tissue types, 
environmental factors, and ecotypes [12, 13]. Many reports have investigated RNA editing in terrestrial plant mitochondria genes, such as cytb, nadI, nad3, coxII, and coxIII $[14,15]$. In ferns, reverse alterations $\mathrm{T}$ to $\mathrm{C}$ were identified in atp1, nad5, rps1, and rpl2 genes [16].

In chloroplast, the activity of NADH dehydrogenase $(\mathrm{NDH})$ complex increases under various environmental conditions, e.g., drought, temperature, and high light stress [17]. RNA editing sites of the ryegrass plastome were investigated in genes encoding $\mathrm{NDH}$ proteins, in particular the $n d h B$ gene [18].

In recent years, next-generation sequencing (NGS) has a rapid and economical way to find organelle RNA editing sites, and extensively examine the whole transcriptome $[8,10]$. Besides these advantages in wide RNA editing detection, NGS technology avoids the limitations of the Sanger method to accurately detect RNA editing in tissue or low-level editing sites that have not been detected before. For example, NGS as well as bioinformatics tools have allowed researchers to identify many novel chloroplast editing sites in Arabidopsis [7, 8, 19].

In our study, we aim to explore the relationship between the light/heat conditions and RNA editing gene wild plants. So, we used RNA-seq data of Calotropis procera leaf tissues to explore these effects.

\section{Methods}

\section{Plant material and RNA extraction}

Triplicates plants of C. procera were used in this study. Three biological leaf disks from each plant per time are mixed. Plants were collected from the KSA western region (Saudi Arabia, latitude $22^{\circ} 16^{\prime} 49.55$, longitude $39^{\circ}$ $7^{\prime}$ 28.18). Three samples were isolated at three different times (dawn, midday, and pre-dusk). Light density/heat temperature was $10 \operatorname{lux} / 35^{\circ} \mathrm{C}$ at dawn, $9000 \operatorname{lux} / 45^{\circ} \mathrm{C}$ at midday, and about 95 lux $/ 37^{\circ} \mathrm{C}$ at pre-dusk. Total RNA was isolated according to Ramadan and Hassanein [20]. RNA concentration was measured at OD $260 \mathrm{~nm}$. Also, the DNA free RNA quality was evaluated by RT-PCR and PCR before sequencing. Samples were deep sequenced in (BGI) Beijing Genomics Institute, China.

\section{Next-generation sequencing (NGS)}

Paired-end short-sequence reads from $C$. procera were developed with Illumina Genome AnalyserIIX (GAIIx). A minimal of 50-bp read with a confidence interval of 95\% was considered for the study. Libraries from leaf tissues were constructed, generating the following raw sequencing reads number 158,537,240 at dawn, 108,554, 060 at midday, and 108,751,224 at pre-dusk with average number of reads that align to known reference bases of $128.72 \mathrm{bp}, 128.69 \mathrm{bp}$, and $119.37 \mathrm{bp}$, respectively.

The RNA sequence reads were submitted to NCBI BioProject with accession numbers PRJNA531450 for dawn transcriptome, PRJNA531451 for midday transcriptome, and PRJNA531452 for pre-dusk transcriptome. RNA editing site was detected by CLC Genomic Workbench 3.6.5 [21]. Mapping parameters were adjusted at a similarity and length fraction of 98 percent. The reads data were mapped to the plastome of Calotropis procera (accession no. MG678914) [22]. The lowfrequency variant $5 \%$ was optimized for a significant. The minimum coverage was 20 , the minimum count was 4 , and the minimum frequency was 5 . In addition, the coverage depth of RNA editing sites and total read counts were reported. The nucleotide conversion frequency of each site was assessed by the number of reads for the conversion of nucleotides divided by total reads [23].

\section{RNA editing and amino acids analysis}

All obtained $n d h B$ sequences, genomic as well as cDNA sequences, were analyzed for RNA editing and corresponding protein using multi-sequence alignment through CLC genomic workbench 3.6.5.

\section{Domain analysis}

NCBI's conserved domain database (CDD) was used to identify the functional domains by submitting the coding sequence of obtained $n d h B$ gene sequence (http://www. ncbi.nlm.nih.gov/Structure/cdd/wrpsb.cgi).

\section{RNA editing site validation and analysis using RT-qPCR}

To validate predicted editing sites, biological triplicates of leaf tissue samples were used. Total RNA was extracted from all the samples using Qiazol (Qiagen, Cat No. 79306).

Each $20 \mu \mathrm{l}$ cDNA synthesis reaction was containing $1 \mu \mathrm{g}$ of total RNA, $1 \mu \mathrm{M}$ poly dT oligonucleotide (Biolegio, Nijmegen, Netherlands), $10 \mu \mathrm{M}-\mathrm{MuLV}$ reaction Mix, $2 \mu \mathrm{l}$ M-MuLV enzyme (New England Biolabs), and then incubation at $42{ }^{\circ} \mathrm{C}$ for $45 \mathrm{~min}$. The $\mathrm{RT}$-PCR reaction was enforced according to Mohammed et al. and Rodrigues et al. [24, 25]. qRT-PCR has a volume of $20 \mu \mathrm{l}$ reaction containing $10 \mu \mathrm{l}$ SsoAdvancedTM Universal ${ }^{\circ}$ SYBR Green Supermix (Bio-RAD, USA), $1 \mu \mathrm{l}$ cDNA, and $10 \mu \mathrm{M}$ each forward and reverse primers (Table 1). Calotropis procera actin gene was used as a reference to normalize data. Applied Biosystems Real-Time PCR (Thermo Fisher Scientific, USA) are used to carry out the following conditions: $5 \mathrm{~min}$ at $94{ }^{\circ} \mathrm{C}, 40$ cycles of $20 \mathrm{~s}$ at $95^{\circ} \mathrm{C}$, and $1 \mathrm{~min}$ at $56^{\circ} \mathrm{C}$. Dissociation curve analysis was carried out by heating at $95^{\circ} \mathrm{C}$ for $60 \mathrm{~s} ; 55^{\circ} \mathrm{C}$ for 30 $\mathrm{s}$, and $0.2^{\circ} \mathrm{C}$ increase per cycle till $95^{\circ} \mathrm{C}$. PCR amplification was done using primers designed by Primer-Blast (https://www.ncbi.nlm.nih.gov/tools/primer-blast/). Two forward specific primers with different 3 ' ends (original and substitute nucleotide) and one reverse primer were 
Table 1 Description of forward (5'-3') and reverse (3'-5') primer sets were designed as two forward specific primers with different 3 ' ends (original and underlined substitute nucleotide) and one reverse primer site except for position 1481, two specific reverse and one forward

\begin{tabular}{|c|c|c|}
\hline Position & F 5' $\rightarrow 3^{\prime}$ & $\mathrm{R} 3^{\prime} \rightarrow 5^{\prime}$ \\
\hline \multirow[t]{2}{*}{467} & TAACTATCTITGTAGCTCI & ATGAAATATTTACTCATGGG \\
\hline & TAACTATCTITGTAGCTCC & \\
\hline \multirow[t]{2}{*}{586} & AAGCTCTTCTATTCTGGTIT & TCTCTCCCCCGGATAAACCAT \\
\hline & AAGCTCTTCTATTCTGGTTC & \\
\hline \multirow[t]{2}{*}{611} & TTCTCTTGGCTATATGGTII & CTGGAGTGGGAGATCCTTCG \\
\hline & TTCTCTTGGCTATATGGTTC & \\
\hline \multirow[t]{2}{*}{737} & ATTGGGTTCAAGCTTTCCCT & TGGAGTGGGAGATCCTTCGT \\
\hline & ATTGGGTTCAAGCTTTCCCC & \\
\hline \multirow[t]{2}{*}{747} & AGCTTTCCCCAGCCCCTTCI & GGCATCTTCTTCTGGAAATC \\
\hline & AGCTTTCCCCAGCCCCTTCC & \\
\hline \multirow[t]{2}{*}{830} & ACTTCGAAAGTAGCTGCTII & AACGTATGCTTGCATATTCG \\
\hline & ACTTCGAAAGTAGCTGCTTC & \\
\hline \multirow[t]{2}{*}{1481} & CGAAACCAAGAAATAACCCCT & CGGGTTCATTGATATTCCT $\underline{\mathbf{A}}$ \\
\hline & & CGGGTTCATTGATATTCCT $\underline{G}$ \\
\hline Actin & TGGTCGTCCAAGACACACTG & СTCTTCAGGGGCAACACGAA \\
\hline
\end{tabular}

designed for each editing site (Table 1). The percentage of RNA editing was performed according to [25]:

$\% R N A$ editing $=\frac{2(\mathrm{Ct} \text { mean of } \mathrm{T} \text { variant }-\mathrm{Ct} \text { mean of } \mathrm{C} \text { variant })}{\{2(\mathrm{Ct} \text { mean of } \mathrm{T} \text { variant }-\mathrm{Ct} \text { mean of } \mathrm{C} \text { variant })+1\}} \times 100$

ANOVA test was conducted in SPSS (20.0; IBM) to assess the variation of editing levels per time. $P$ values $<0.01$ were considered significant according to Tukey's test.

\section{D structure alignment}

Modeling pairwise alignment was achieved by I-TASSER, (Iterative Threading ASSEmbly Refinement) for three ndhB proteins (dawn, midday, and pre-dusk) as well as correspondence protein of DNA coding sequence. This approach predicts protein structure and function [26].

\section{Results}

Identification of $C$. procera $n d h B$ gene

The Calotropis procera $n d h B$ gene was characterized via this study (accession number MK144329) using short DNA sequence reads 71,349,934 paired ends (BioSample Accession Numbers PRJNA292713). Calotropis procera chloroplast gene $n d h B$ (accession no. MG678914) of $t$ was used as reference in CLC genomic workbench. Multi-sequence alignment was enforced using the best hits of BLAST search (Table 2, Fig. S1).

\section{Characterization of ndhB mRNA}

cDNA $n d h B$ gene of $C$. procera at dawn (accession no. MK165161), at midday (accession no. MK165160), and at pre-dusk (accession no. MK165159) were characterized using RNA-seq raw data. A total of 215,841,902 paired-end short sequence reads of the RNA $C$. procera were generated. In a CLC genomic workbench, $n d h B$ gene (accession no. MK144329) of C. procera was used as a template.

\section{RNA editing in $n d h B$ transcript}

A comparison of genomic $n d h B$ sequences with 3-times cDNA (Fig. S2) showed conversion of $\mathrm{C}$ to $\mathrm{U}$ in 7 RNA positions (nucleotide no. C467, C586, C611, C737, C746, C830, and C1481). Since the rate editing is less than $50 \%$ in all transcripts (Fig. 1, Table S1), there was another editing site in C830 that does not appear in Fig. S2. The previous RNA editing resulted in the substitution of 7 amino acids: (i) three proline to leucine (P-L), (ii) two serine to leucine (S-L), (iii)

Table 2 Accession number for each DNA sequence, description, organism name, T.S., \% ident., and E value of homologous sequence to $C$. procera ndhB gene sequence identified using BLAST programs

\begin{tabular}{|c|c|c|c|c|}
\hline Accession number & Description & T.S. & $\%$ ident. & $E$ value \\
\hline MH939982 & Calotropis procera chloroplast & 8190 & 100 & 0.0 \\
\hline MH939981.1 & Calotropis gigantea chloroplast & 8190 & 100 & 0.0 \\
\hline KF539850.1 & Matelea biflora plastid, partial genome & 4095 & 100 & 0.0 \\
\hline MG678915.1 & Pergularia daemia voucher OKLA chloroplast & 4089 & 99 & 0.0 \\
\hline MG678876.1 & Asclepias mellodora var. mellodora & 4089 & 99 & 0.0 \\
\hline MG678856.1 & Asclepias pilgeriana chloroplast, partial genome & 4089 & 99 & 0.0 \\
\hline MG678843.1 & Asclepias boliviensis chloroplast, partial genome & 4089 & 99 & 0.0 \\
\hline MG678835.1 & Asclepias aff. aequicornu chloroplast, partial genome & 4089 & 99 & 0.0 \\
\hline KF539853.1 & Telosma cordata plastid, partial genome & 4089 & 99 & 0.0 \\
\hline KF539852.1 & Sisyranthus trichostomus plastid, partial genome & 4089 & 99 & 0.0 \\
\hline
\end{tabular}




\begin{tabular}{|c|c|c|c|c|c|c|c|}
\hline & & 20 & & $\begin{aligned} 40 \\
1\end{aligned}$ & & $\begin{array}{c}60 \\
1\end{array}$ & \\
\hline ndhB intronless translation frame +1 & MIWHVQNENF & I LDSTR I FMK & AFHLLLFDGS & LIFPECILIF & GL I LLLMID I & TSDQKD I PWL & 60 \\
\hline MK165161 translation frame +1 & $\ldots \ldots \ldots$ & $\ldots \ldots \ldots$ & $\ldots \ldots \ldots$ & $\ldots \ldots \ldots$ & $\ldots \ldots \ldots$ & $\ldots \ldots \ldots$ & 60 \\
\hline MK165160 translation frame +1 & $\ldots \ldots \ldots$ & $\ldots \ldots \ldots$ & $\ldots \ldots \ldots$ & $\ldots \ldots \ldots$ & $\ldots \ldots \ldots$ & $\ldots \ldots \ldots$ & 60 \\
\hline MK165159 translation frame +1 & $\ldots \ldots \ldots$ & $\cdots \cdots \cdots \cdots \underset{\substack{80 \\
1}}{2}$ & $\ldots \ldots \ldots$ & $\cdots \cdots \cdots \underbrace{}_{\substack{100 \\
1}}$ & $\ldots \ldots \ldots$ & $\cdots \cdots \cdots \cdots \underset{120}{120}$ & 60 \\
\hline ndh $B$ intronless translation frame +1 & YFISSTSLVM & S I TALLFRWR & EEPMISFSGN & FQTNNFNE I F & QFLI LLCSTL & CIPLSVEYIE & 120 \\
\hline MK165161 translation frame +1 & $\ldots \ldots \ldots$ & $\ldots \ldots \ldots$ & $\ldots \ldots \ldots$ & $\ldots \ldots \ldots$ & $\ldots \ldots \ldots$ & $\ldots \ldots \ldots$ & 120 \\
\hline MK165160 translation frame +1 & $\ldots \ldots \ldots$ & $\ldots \ldots \ldots$ & $\ldots \ldots \ldots$ & $\ldots \ldots \ldots$ & $\ldots \ldots \ldots$ & $\ldots \ldots \ldots$ & 120 \\
\hline MK165159 translation frame +1 & $\ldots \ldots \ldots$ & $\cdots \cdots \cdots \cdots$ & $\ldots \ldots \ldots$ & $\cdots \cdots \cdots \underset{\substack{160 \\
1}}{.}$ & $\ldots \ldots \ldots$ & $\cdots \cdots \cdots \cdots$ & 120 \\
\hline ndh $B$ intronless translation frame +1 & CTEMA I TEFL & LFVLTATLGG & MF LCGANDF I & TIFVAPECFS & LCSYLLSGYT & KKDVRSNEAT & 180 \\
\hline MK165161 translation frame +1 & $\ldots \ldots \ldots$ & $\ldots \ldots \ldots$ & $\ldots \ldots \ldots$ & $\ldots \ldots \mathrm{L} \ldots$ & $\ldots \ldots \ldots$ & $\ldots \ldots \ldots$ & 180 \\
\hline MK165160 translation frame +1 & $\ldots \ldots \ldots$ & $\ldots \ldots \ldots$ & $\ldots \ldots \ldots$ & $\ldots \ldots \mathrm{L} \ldots$ & $\ldots \ldots \ldots$ & $\ldots \ldots \ldots$ & 180 \\
\hline MK165159 translation frame +1 & $\ldots \ldots \ldots$ & $\cdots \cdots W_{200}$ & $\ldots \ldots \ldots$ & $\cdots \cdots L^{220}$ & $\ldots \ldots \ldots$ & $\cdots \cdots \cdots{ }_{240}$ & 180 \\
\hline ndhB intronless translation frame +1 & MKYLLMGGAS & SSILVHGFSW & LYGSSGGE IE & LQE I VNGL IN & TQMYNSPGIS & IAL I F I TVG I & 240 \\
\hline MK165161 translation frame +1 & $\ldots \ldots \ldots$ & $\ldots$. . . & $\ldots \mathrm{L} \ldots \ldots$ & $\ldots \ldots \ldots$ & $\ldots \ldots \ldots$ & $\ldots \ldots \ldots$ & 240 \\
\hline MK165160 translation frame +1 & $\ldots \ldots \ldots$ & $\ldots \ldots$. . & $\ldots \mathrm{L}$ & $\ldots \ldots$ & $\ldots \ldots \ldots$ & $\ldots$ & 240 \\
\hline MK165159 translation frame +1 & $\ldots \ldots \ldots$ & $\ldots \ldots Y \ldots$ & $\ldots$ L $\ldots \ldots$ & $\cdots \cdots \cdots \cdots$ & $\ldots \ldots \ldots$ & $\cdots \cdots \cdots$ & 240 \\
\hline ndh $B$ intronless translation frame +1 & GFKLSPAPSH & QWTPDVYEGS & PTPVVAFLSV & TSKVAASALA & TRIFDIPFYF & SSNEWHLLLE & 300 \\
\hline MK165161 translation frame +1 & $\ldots$ L.F. & $\ldots \ldots \ldots$ & $\ldots \ldots \ldots$ & $\ldots \ldots \ldots$ & $\ldots \ldots \ldots$ & $\ldots \ldots \ldots$ & 300 \\
\hline MK165160 translation frame +1 & $\ldots \ldots \ldots$ & $\ldots \ldots \ldots$ & $\ldots \ldots \ldots$ & $\ldots \ldots \ldots \ldots$ & $\ldots \ldots \ldots$ & $\ldots \ldots \ldots$ & 300 \\
\hline MK165159 translation frame +1 & $\ldots \ldots \ldots$ & $\cdots \cdots \cdots \cdots$ & $\ldots \ldots \ldots$ & $\cdots \cdots \cdots \underset{\frac{340}{1}}{ }$ & $\ldots \ldots \ldots$ & $\cdots \cdots \cdots \underset{\substack{360 \\
1}}{.}$ & 300 \\
\hline ndh $B$ intronless translation frame +1 & ILA I LSM ILG & NLIA I TQTSM & KRMLAYSS IG & QIGYVIIGII & VGDSNDGYAS & MITYMLFYIS & 360 \\
\hline MK165161 translation frame +1 & $\ldots \ldots \ldots$ & $\ldots \ldots \ldots$ & $\ldots \ldots \ldots$ & $\ldots \ldots \ldots \ldots$ & $\ldots \ldots \ldots$ & $\ldots \ldots \ldots$ & 360 \\
\hline MK165160 translation frame +1 & $\ldots \ldots \ldots$ & $\ldots \ldots \ldots$ & $\ldots$ & $\ldots \ldots \ldots$ & & $\ldots$ & 360 \\
\hline MK165159 translation frame +1 & $\ldots \ldots \ldots$ & $\cdots \cdots \cdots{ }_{380}^{38}$ & $\ldots \ldots \ldots$ & $\cdots \cdots{ }_{400}$ & $\ldots \ldots$ & $\cdots \cdots \cdots$ & 360 \\
\hline ndh $B$ intronless translation frame +1 & MNLGTFACIV & LFGLRTGTDN & I RDYAGLYTK & DPFLALSLAL & CLLSLGGLPP & LAGFFGKLYL & 420 \\
\hline MK165161 translation frame +1 & $\ldots \ldots \ldots$ & $\ldots \ldots \ldots$ & $\ldots \ldots \ldots$ & $\ldots \ldots \ldots$ & $\ldots \ldots \ldots$ & $\ldots \ldots \ldots$ & 420 \\
\hline MK165160 translation frame +1 & $\ldots \ldots \ldots$ & $\ldots \ldots \ldots$ & $\ldots \ldots \ldots$ & $\ldots \ldots \ldots$ & $\ldots \ldots \ldots$ & $\ldots \ldots \ldots$ & 420 \\
\hline MK165159 translation frame +1 & $\ldots \ldots \ldots$ & $\cdots \cdots \cdots \cdots$ & $\ldots \ldots \ldots$ & $\cdots \cdots \cdots{ }_{460}^{460}$ & $\ldots \ldots \ldots$ & $\cdots \cdots \cdots \cdots$ & 420 \\
\hline ndhB intronless translation frame +1 & FWC GWQAGLY & FLVL I GLLTS & VVSIYYYLKI & I KLLMTGRNQ & EITPHVRNYR & RSPLRSNNSI & 480 \\
\hline MK165161 translation frame +1 & $\ldots \ldots \ldots$ & $\ldots \ldots \ldots$ & $\ldots \ldots \ldots$ & $\ldots \ldots \ldots$ & $\ldots \ldots \ldots$ & $\ldots \ldots \ldots$ & 480 \\
\hline MK165160 translation frame +1 & $\ldots \ldots \ldots$ & $\ldots \ldots \ldots$ & $\ldots \ldots \ldots$ & $\ldots \ldots \ldots$ & $\ldots \ldots \ldots$ & $\ldots \ldots \ldots$ & 480 \\
\hline MK165159 translation frame +1 & $\ldots \ldots \ldots$ & $\cdots \cdots \cdots \underbrace{}_{\substack{500 \\
1}}$ & $\ldots \ldots \ldots$ & $\ldots \ldots \ldots$ & $\ldots \ldots \ldots$ & $\ldots \ldots \ldots$ & 480 \\
\hline ndhB intronless translation frame +1 & ELSMIVCVIA & STIPGISMNP & I I A I AQDT LF & * 511 & & & \\
\hline MK165161 translation frame +1 & $\ldots \ldots \ldots$ & $\ldots \mathrm{L} \ldots \ldots$ & $\ldots \ldots \ldots$ & . 511 & & & \\
\hline MK165160 translation frame +1 & $\ldots \ldots \ldots$ & $\ldots \mathrm{L} \ldots \ldots$ & $\ldots \ldots \ldots$ & . 511 & & & \\
\hline MK165159 translation frame +1 & $\ldots \ldots \ldots$ & $\ldots$ L. . . & $\ldots$ & . 511 & & & \\
\hline
\end{tabular}

one serine to phenylalanine (S-F), and (iv) one histidine to tyrosine (H-Y) (Fig. 1, Fig. S2, Table S1).

\section{Analysis of the deduced protein sequence and conserved domain}

The current effect of editing the RNA must be measured at the level of protein. The sequences of amino acids derived from $C$. procera genomic and complementary
DNA (cDNA) were compared with the amino acid profile of other species derived from cDNA. This comparison clearly demonstrated that the editing in $n d h B$ gene in $C$. procera led to the formation of conserved amino acid (Fig. 2). Domain analysis refers to the activity of chloroplast NADH-plastoquinone oxidoreductase subunit $2(n d h B)$ and CDD accession number cl00535, and Pfam, PF00507 (Fig. 3).

$\begin{aligned} & \text { RF +1 } \\ & \text { Specific hits } \\ & \text { Superfanilies }\end{aligned}$
Proton_antipo_M superfamily

Fig. 2 Protein domains of the deduced amino acid sequence of the obtained ndhB protein (RF) 


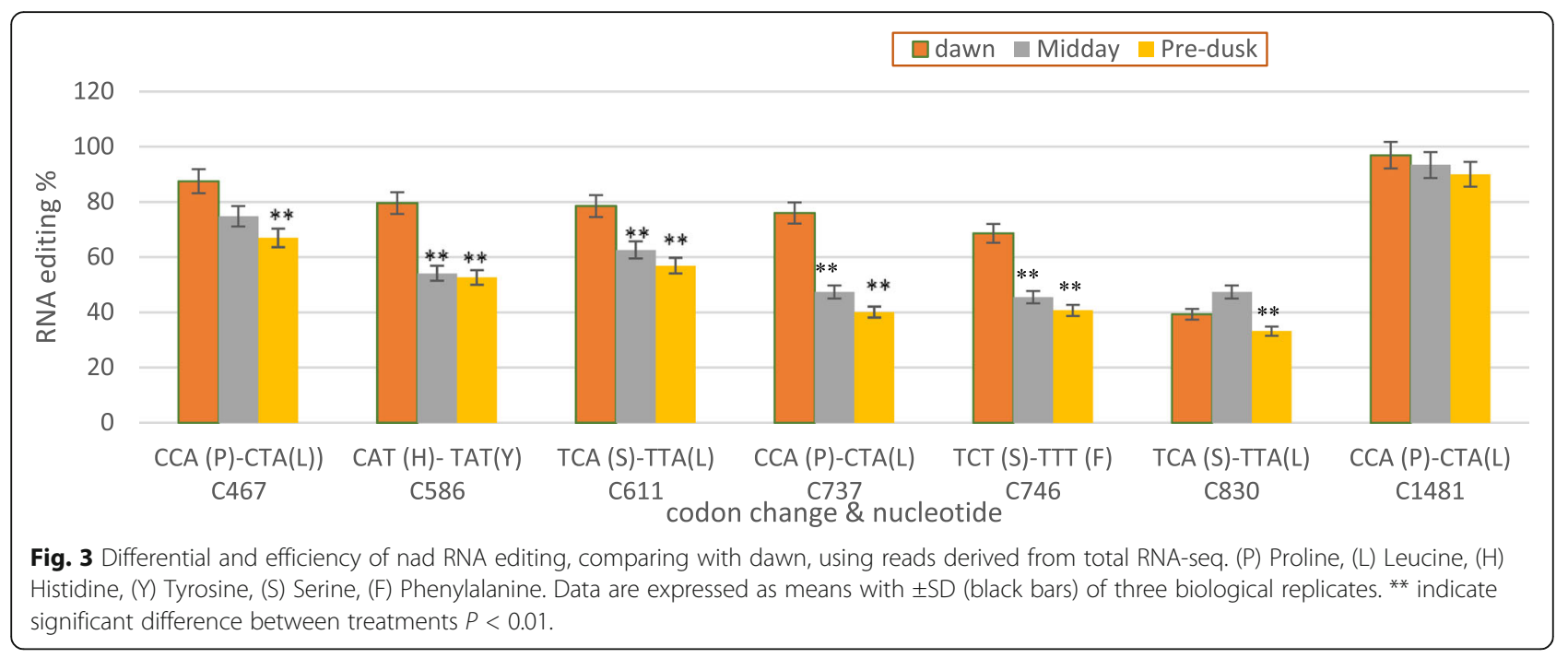

\section{Validation of editing in $n d h B$ gene}

To validate candidate editing sites, and clarify the importance of RNA-seq tool in RNA editing identification, the seven editing sites were analyzed using RT-qPCR. The $n d h B$ editing positions (C467, C586, C611, C737, C746, 830, and C1481) were comparatively quantified in three light periods (Fig. 4). RT-qPCR data confirmed that the editing percentage was the highest at dawn except in C830 which was higher at midday. Data were analyzed using CLC genomic workbench version 3.6.5.

\section{D structure alignment}

$3 \mathrm{D}$ models of three times $n d h B$ proteins structure as well as correspondence protein of DNA coding sequence are compared. The result showed changes in three loops region in $n d h B$ protein at dawn, and one at midday; however, the protein at pre-dusk was identical to midday in shape (Fig. 5).

\section{Discussion}

RNA editing is common in terrestrial plants, especially in the mitochondria $[5,12,27]$ and chloroplast $[7,28]$. It plays a crucial role in the expression of functional proteins, like RNA editing in Nicotiana tomentosiformis ndhD-1 site which restore a translational initiation codon ATG from ACG on its DNA regulates the translation efficiency [29]. But, the lower level of RNA editing at some sites does not affect in accumulation of chloroplast NDH complex in Nicotiana tomentosiformis [30]. Otherwise, the disturbance of $\mathrm{C} 250$ editing in mitochondrial Nad dehydrogenase subunit 3 (nad3) gene results in the accumulation of large reactive oxygen species (ROS) concentrations, leading to a deterioration of Arabidopsis drought tolerance [31].

RNA editing in $n d h B$ gene was reported since three decades [32]. RNA editing in $n d h B$ gene was detected at 9 sites in Arabidopsis (Arabidopsis thaliana), 10 in rice, 13 in soybean [7, 25], and 8 in Crambe (Crambe abyssinica) [33]. In this study, seven editing sites of $C$. procera

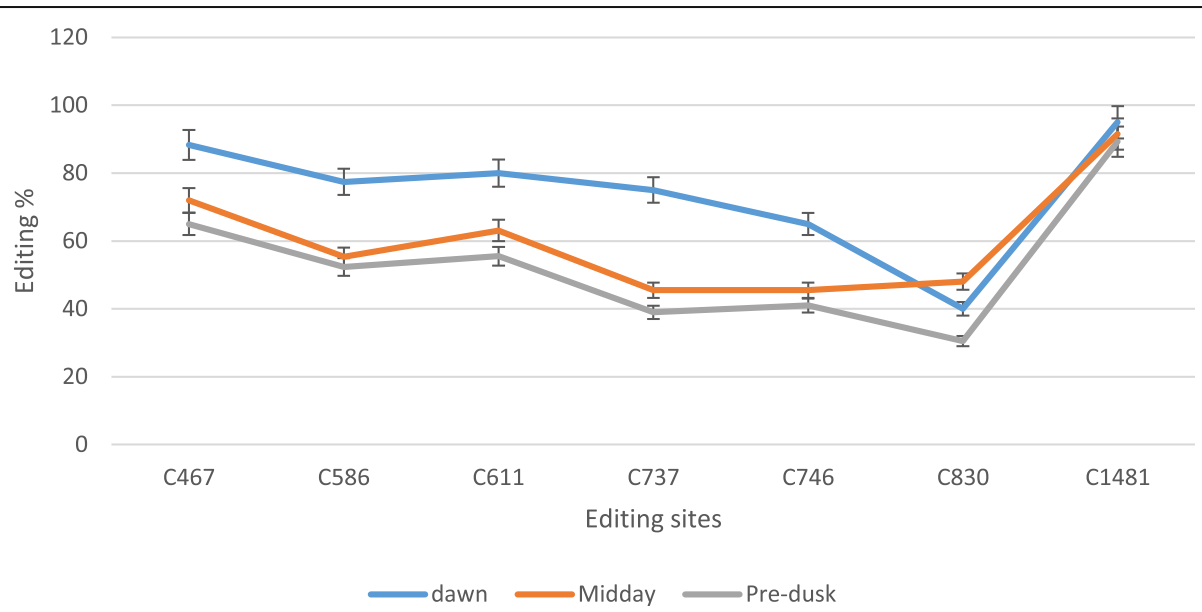

Fig. 4 QRT-PCR confirmation of Calotropis procera ndhB editing sites predicted by CLC genomic workbench in different 3 times (dawn, midday, and pre-dusk). Data are expressed as means with \pm SD (black bars) of three biological replicates 

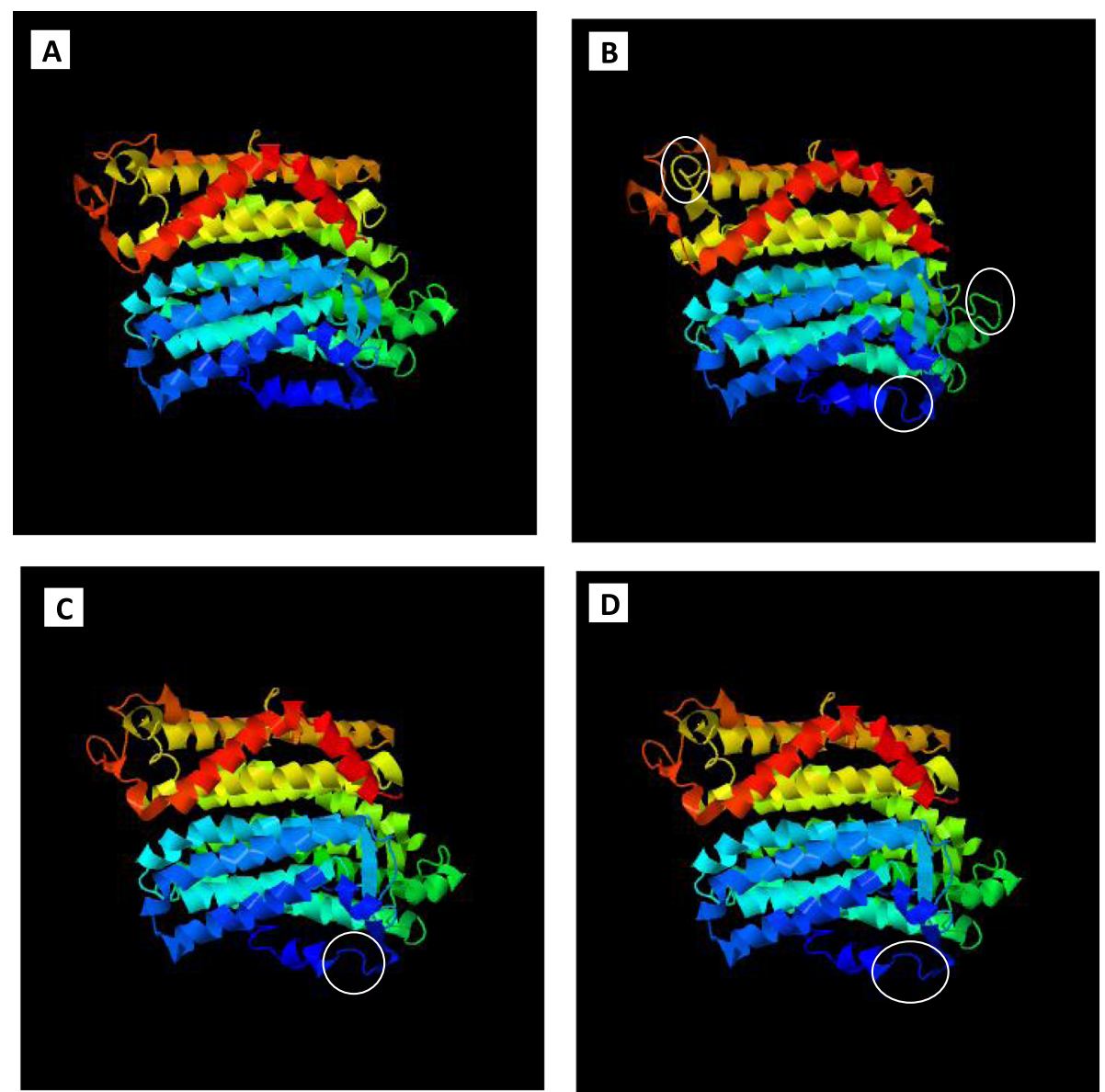

Fig. 5 3D model of C. procera ndhB protein in different three times as well as original protein. a Predicted 3D protein of correspondence DNA coding sequence. $\mathbf{b}$ Predicted 3D protein at dawn. c Predicted 3D protein at midday. $\mathbf{d}$ Predicted 3D protein at pre-dusk, white circle showed the differences in loop domains occurred from RNA editing

ndhB gene (C467, C586, C611, C737, C746, C830, and C1481) were deferentially edited across three daylight periods. These sites were validated by qRT-PCR. The identified edited sites in C. procera were concordant with previous research achieved by [25]. However, there were five other editing sites (C836, C1112, C1255, C1391, and C1414) reported by the same study [25], and they were not found in $n d h B$ transcript in C. procera. Most of the non-editing sites were unchanged because they were $T$, not $C$, in the target gene. Furthermore, RNA editing rate of $n d h B$ gene was highest at dawn, $(87.5,79.6,78.5,76,68.6,39.3$, and $96.9 \%$, respectively), less at midday $(74.8,54.1,62.6,47.4,45.5,47.4$, and $93.4 \%$, respectively), and lowest at pre-dusk $(67,52.6$, $56.9,40.1,40.7,33.2$, and $90 \%$, respectively). RNA editing can modify hydrophilic amino acids to hydrophobic amino acids and occur at locations necessary for 3D protein structure formation and protein folding [34]. The produced 3D structure of three times ndhB protein showed differential structure in dawn and midday due to differential in RNA editing. This indicate to the protein function and activity is affected by RNA editing as reported in previous studies $[35,36]$.
These results indicated that light period may affect the rate of RNA editing without induction of new editing sites. From current results, we do speculate that photosynthesis in this desert plant may reach its maximum during dawn daylight time. In fact, RNA editing may increase hydrophobicity of protein and its affinity to phospholipids in the chloroplast's membrane $[35,36]$. However, such hypothesis needs to be investigated and it will be the subject of our future studies.

\section{Conclusion}

In $n h d B$ transcript in C. procera, comprehensive editing takes place at 7 sites; these editing sites were primarily conserved through plant species. The differential editing of this gene across light periods may be led to a somehow relations between the RNA editing and control of photosynthesis. The main limitation of the study was the lack of understanding of how the light may control the level of RNA editing in the chloroplast in C. procera, which will be the main focus of future research taking into consideration circadian changes can occur. 


\section{Supplementary information}

Supplementary information accompanies this paper at https://doi.org/10. 1186/s43141-020-00064-4.

Additional file 1: Table S1. NdhB C-to- $U$ editing events using reads derived from total RNA-seq.

Additional file 2:. Fig. S1 Multi-sequence alignment was enforced using the best hits of BLAST search.

Additional file 3: Fig S2. A comparison between $n d h B$ sequences of the genomic DNA and 3 times CDNA revealed RNA editing sites.

\section{Abbreviations}

Nad: Nad dehydreogenase; Cytb: Cytochrome b reductase; COX: Cytochrome c oxidase; apobec: Apolipoprotein-B catalytic subunit; ACF: Apobec-1 complementation factor; atp1: Atp synthase subunit 1; nad3: Nad dehydreogenase gene subunit 3; nad5: Nad dehydreogenase gene subunit 5; rpl2: Ribosomal protein L2; rps1: Ribosomal protein S1

\section{Acknowledgements}

The author acknowledges with thanks the Saudi Basic Industries Corporation (SABIC) and the Deanship of Scientific Research (DSR) at King Abdulaziz University, Jeddah, for technical and financial support.

\section{Author's contributions}

All work is achieved by AMR. The author(s) read and approved the final manuscript.

\section{Funding}

This project was funded by the Saudi Basic Industries Corporation (SABIC) and the Deanship of Scientific Research (DSR) at King Abdulaziz University, Jeddah, under grant no. S-86-130-1441.

\section{Availability of data and materials}

All data generated or analyzed during this study are included in this published article [and its supplementary information files].

\section{Ethics approval and consent to participate}

This article does not contain any studies with human participants or animals performed by the author.

\section{Consent for publication}

Not applicable

\section{Competing interests}

The authors declare that they have no competing interests.

Received: 8 July 2020 Accepted: 2 September 2020

Published online: 11 September 2020

\section{References}

1. Nishikura K (2006) Editor meets silencer: crosstalk between RNA editing and RNA interference. Nat Rev Mol Cell Biol 7(12):919-931

2. Farajollahi S, Maas S (2010) Molecular diversity through RNA editing: a balancing act. Trends Genet 26(5):221-230

3. Benne R, Van den Burg J, Brakenhoff JP et al (1986) Major transcript of the frame shifted coxll gene from trypanosome mitochondria contains four nucleotides that are not encoded in the DNA. Cell 46(6):819-826

4. Maris C, Masse J, Chester A et al (2005) NMR structure of the apoB mRNA stem-loop and its interaction with the $\mathrm{C}$ to $\mathrm{U}$ editing APOBEC 1 complementary factor. RNA 11(2):173-186

5. Castandet B, Araya A (2011) RNA editing in plant organelles. Why make it easy? Biochemistry Moscow 76(8):924-931

6. Takenaka M, Jörg A, Burger M et al (2019) RNA editing mutants as surrogates for mitochondrial SNP mutants. Plant Physiol Biochem 135:310-321

7. Ruwe H, Castandet B, Schmitz-Linneweber C, Stern DB (2013) Arabidopsis chloroplast quantitative editotype. FEBS Lett 587:1429-1433

8. Bentolila S, Oh J, Hanson MR et al (2013) Comprehensive high-resolution analysis of the role of an Arabidopsis gene family in RNA editing. PLoS Genet 9(6):e1003584
9. Licht K, Jantsch MF (2016) Rapid and dynamic transcriptome regulation by RNA editing and RNA modifications. J Cell Biol 213(1):15-22

10. Picardi E, D'Erchia AM, Gallo A et al (2014) Uncovering RNA editing sites in long non-coding RNAs. Front Bioeng Biotechnol 2:64

11. Edera AA, Gandini CL, Sanchez-Puerta MV (2018) Towards a comprehensive picture of C-to-U RNA editing sites in angiosperm mitochondria. Plant Mol Biol 97(3):215-231

12. Bentolila S, Elliott LE, Hanson MR (2008) Genetic architecture of mitochondrial editing in Arabidopsis thalliana. Genetics 178(3):1693-1708

13. Tseng CC, Lee CJ, Chung YT, Sung TY, Hsieh MH (2013) Differential regulation of Arabidopsis plastid gene expression and RNA editing in nonphotosynthetic tissues. Plant Mol Biol 82(4-5):375-392

14. Takenaka M, Verbitskiy D, Merwe JA et al (2008) The process of RNA editing in plant mitochondria. Mitochondrion 8(1):35-46

15. Wang C, Chen X, Li H et al (2007) RNA editing analysis of mitochondrial nad3/rps12 genes in cytoplasmic male sterility and male-fertile cauliflower (Brassica oleracea var. botrytis) by CDNA-SSCP. Bot Stud 48(1):13-23

16. Knie N, Grewe F, Fischer S et al (2016) Reverse U-to-C editing exceeds C-to$U$ RNA editing in some ferns-a monilophyte-wide comparison of chloroplast and mitochondrial RNA editing suggests independent evolution of the two processes in both organelles. BMC Evol Biol 16:134

17. Ibanez H, Ballester A, Munoz R et al (2010) Chlororespiration and tolerance to drought, heat and high illumination. J Plant Physiol 167:732-738

18. Diekmann K, Hodkinson TR, Wolfe KH et al (2009) Complete chloroplast genome sequence of a major allogamous forage species, perennial ryegrass (Lolium perenne L.). DNA Res 16:165-176

19. Lo Giudice C, Hernández I, Ceci LR et al (2019) RNA editing in plants: a comprehensive survey of bioinformatics tools and databases. Plant Phys Bioch 137:53-61

20. Ramadan AM, Hassanein SE (2014) Detection of P5CS gene in Calotropis procera plant from the de novo assembled transcriptome contigs of the high-throughput sequencing dataset. C R Biol 337(12):683-690

21. Ishii S, Suzuki S, Norden-Krichmar TM et al (2013) A novel metatranscriptomic approach to identify gene expression dynamics during extracellular electron transfer. Nat Commun 4:160

22. Fishbein M, Straub SCK, Boutte J et al (2018) Evolution at the tips: Asclepias phylogenomics and new perspectives on leaf surfaces. Am J Bot 105(3): 514-524

23. Wang M, Cui L, Feng K, Deng P, Du X, Wan F, Weining S, Nie X (2015) Comparative analysis of Asteraceae chloroplast genomes: structural organization, RNA editing and evolution. Plant Mol Biol Rep 33(5):1526-1538

24. Mohammed A, Diab MR, Abdelsattar M, Khalil S (2017) Characterization and RNAi-mediated knockdown of chitin synthase a in the potato tuber moth, Phthorimaea operculella. Sci Rep 7(1):9502

25. Rodrigues NF, Christoff AP, da Fonseca GC et al (2017) Unveiling chloroplast RNA editing events using next generation small RNA sequencing data. Front Plant Sci 8:1686

26. Yang J, Zhang Y (2015) I-TASSER server: new development for protein structure and function predictions. Nucleic Acids Res 43:174-181

27. Chateigner-Boutin AL, Small I (2007) A rapid high-throughput method for the detection and quantification of RNA editing based on high-resolution melting of amplicons. Nucleic Acids Res 35(17):e114

28. Takenaka M, Zehrmann A, Verbitskiy D et al (2013) RNA editing in plants and its evolution. Annu Rev Genet 47:335-352

29. Hirose T, Sugiura M (1997) Both RNA editing and RNA cleavage are required for translation of tobacco chloroplast ndhD mRNA: a possible regulatory mechanism for the expression of a chloroplast operon consisting of functionally unrelated genes. EMBO J 16:6804-6811

30. Okuda K, Habata Y, Kobayashi $Y$ et al (2008) Amino acid sequence variations in Nicotiana CRR4 orthologs determine the species-specific efficiency of RNA editing in plastids. Nucleic Acids Res 36:6155-6164

31. Yuan H, Liu D (2012) Functional disruption of the pentatricopeptide protein SLG1affects mitochondrial RNA editing, plant development, and responses to abiotic stresses in Arabidopsis. Plant J 70:432-444

32. Maier RM, Neckermann K, Hoch B et al (1992) Identification of editing positions in the $\mathrm{ndhB}$ transcript from maize chloroplasts reveals sequence similarities between editing sites of chloroplasts and plant mitochondria. Nucleic Acids Res 20(23):6189-6194

33. Amanda DS, Túlio GP, Leila DN et al (2018) The Crambe abyssinica plastome: Brassicaceae phylogenomic analysis, evolution of RNA editing sites, hotspot and microsatellite characterization of the tribe Brassiceae. Gene 671:36-49 
34. Yura, K, Go M (2008) Correlation between amino acid residues converted by RNA editing and functional residues in protein three-dimensional structures in plant organelles. BMC Plant Biol. doi.org/https://doi.org/10.1186/14712229-8-79

35. Moreira S, Valach M, Aoulad-Aissa M et al (2016) Novel modes of RNA editing in mitochondria. Nucleic Acids Res 44(10):4907-4919

36. Ramadan AM (2020) Salinity effects on nad3 gene RNA editing of wild barley mitochondria. Mol Biol Reports 47(5):3857-3865

\section{Publisher's Note}

Springer Nature remains neutral with regard to jurisdictional claims in published maps and institutional affiliations.

\section{Submit your manuscript to a SpringerOpen ${ }^{\circ}$ journal and benefit from:}

- Convenient online submission

- Rigorous peer review

- Open access: articles freely available online

- High visibility within the field

- Retaining the copyright to your article

Submit your next manuscript at $\boldsymbol{\nabla}$ springeropen.com 